\title{
Effect of discharge plan on patients' readiness to discharge after allogeneic stem cells transplantation
}

The aim of the study is to evaluate the effect of discharge plan on patients' readiness to discharge after allogeneic stem cells transplantation. To fulfill the aim of the present study one group pre-post-test quasi-experimental design was utilized. A purposive sample of 30 patients after allogeneic hematopoietic stem cells transplantation (AHSCT) was selected over a period of 3 months. Four tools were selected to evaluate patients' readiness to discharge post (AHSCT). (I) structured interview questionnaire (which developed by the researcher), (II) Tool Adapted Piper Fatigue Scale (PFS), (III) adapted Hospital Anxiety and Depression Scale (HADS), and (IV) pre-post patients' knowledge assessment test (which developed by the researcher). More than seventy percent of patients had unaccepted level of fatigue (moderate fatigue level), more than seventy five of patients had no anxiety and more than sixty of them had no depression, and total number of patients had accepted level of knowledge after conducting discharge plan. Based on the results of the current study it could be concluded that; combination of informational structures with different types of exercises as (range of motion \& pursed lips breathing exercises) can improve psychological status (decrease level of anxiety and depression) and raise awareness about home care after hospital discharge for patients post (AHSCT). Performing of (ROM \&pursed lips breathing) exercises for short time cannot improve fatigue level for these patients.

\section{Keywords: discharge plan, readiness to discharge}

\section{List of abbreviation}

AHSCT: Allogeneic Hematopoietic Stem Cells Transplantation; GVHD: Graft Versus Host Disease; ICU: Intensive Care Unit; PFS: Piper Fatigue Scale; HADS: Hospital Anxiety and Depression Scale; HESCs: Human embryonic stem cells; MUD: Matched Unrelated Donor; VOD: Veno-Occlusive Disease; EBV: Epstein-Barr Virus; ANC: Absolute Neutrophil Count; CVC: Central Venous Catheter; NSF: National Sanitation Foundation; ROM: Range of Motion; NSAIDs: Nonsteroidal Anti-Inflammatory Drugs; SCT: Stem cell transplantation

\section{Aim of the study}

The aim of the proposed study is to evaluate the effect of discharge plan on patients' readiness to discharge after allogeneic stem cells transplantation.

Motivation to perform the current study A total of 1 million stem cell transplants have been performed worldwide with increasing 45,000 patients annually [1]. Many studies performed about quality of life for patients after hematopoietic stem cell transplantation and concluded that; readmission rates were increased resulting from lack of information and patients' preparation before discharge.

\section{Introduction}

Stem cell is a one of the human body's master cells; it has the remarkable potential to develop into many different cell types in the body during early life and growth. In addition, in many tissues they serve as a sort of internal repair system, dividing essentially without limit to replenish other cells as long as the person or animal is still alive. Stem cells are divided to three sources.

a) Embryonic stem cells, they are developed from eggs that have been fertilized in vivo or in vitro within 8 weeks.

b) Umbilical cord stem cells, that come from a newborn's umbilical cord and can be collected immediately after birth.

c) Adult stem cells also referred to as somatic stem cells, it is present in adults, children, and infants. Adult stem cells are divided to two
Shaimaa Raafat Ali $^{1}$, Khairia Abo Bakr Elsawi ${ }^{1}$, Hanaa Youssry Hashem ${ }^{1}$ \& Gamal Eldin Mohammed Fathy ${ }^{2}$

${ }^{1}$ Faculty of Nursing, Cairo University, Egypt

${ }^{2}$ Consultant of Hematological Diseases and Bone Marrow Transplantation Nasser Institute for Research and Treatment, Egypt

*Author for correspondence: cati_0@yahoo.com 
types, undifferentiated and hematopoietic stem cells [2].

Undifferentiated stem cells are found in small number among differentiated cells including blood vessels, skeletal muscle, skin, teeth, heart, gut, liver, ovarian epithelium, and testis, while hematopoietic stem cells are present mainly in bone marrow and peripheral blood and forms all types of blood cells in the body such as red blood cells, B lymphocytes, T lymphocytes, natural killer cells, neutrophils, basophils, eosinophils, monocytes, and macrophages. Undifferentiated and hematopoietic stem cells can be used in stem cells therapy $[3,5]$.

Stem cell therapy (also called cellular therapy, cytotherapy or regenerative medicine) is a therapy in which cellular material is injected into a patient; for example $\mathrm{T}$ cells capable of fighting cancer cells via cell-mediated immunity may be injected in the course of immunotherapy [2]. Stem cells can be transplanted to the human body through three methods:

a) Autologous method, it occurs when donor and recipient is the same person,

b) Syngeneic method, it means that patient receives stem cells from identical twins, and

c) Allogeneic method, it occurs when stem cells are derived from another source rather than the patient. The patient could be transplanted using either peripheral blood or bone marrow [3].

The impact of allogeneic hematopoietic stem cell transplantation (AHSCT) can cause multiple hospital readmissions due to physical complications such as infection, fatigue, bleeding, pain and rejection of new stem cells called graft versus host disease (GVHD), psychological complications including anxiety, stress and depression and social complications such as social isolation. Most of these complications can result from inadequate patients' preparation to hospital discharge or absence of discharge planning [4].

Discharge planning is an important part of any hospital admission. It plays an important role in ensuring a smooth move from hospital to home. The process of discharge planning often resembles the construction of a jigsaw puzzle: available pieces are placed carefully in relation to other pieces so that together they contribute to the whole picture. The challenge of discharge planning, like that for completing puzzle, is to find missing pieces that are just the right size and shape and then place them securely in the right position. A clear idea of the finished picture or outcome improves the effectiveness of the discharge planning process [5].

Discharge planning is a plan of care that starts from first day of admission with the aim of preparing the patient to move from one level of care to another; for example, moving the patient from recovery room to intensive care unit (ICU), from ICU to different medical or surgical ward or from hospital to home [6]. Planning for a patient's post discharge care does not begin on the day when decision is made to release the patient from the hospital. It is generally accepted that discharge planning should start prior to admission for planned admission or at the time of admission for unplanned admission. Four stages are integrated to complete safe hospital discharge planning which include a) assessment of patient, b) development of an initial discharge plan, c) implementation of the plan, and d) assessment of the patient readiness to discharge $[5,6]$.

Patients' readiness to discharge means that; physical and psychological ability of the patient to relocate from one level of care to lower level including home (Cochrane review brief: discharge planning from hospital to home, 2015). For patients after (AHSCT) criteria for readiness to discharge include physical readiness in term of (hemodynamic stability), fatigue level, presence of pain, psychological readiness observed by assessing level of anxiety and depression and patients' information about home care [7]. Therefore, the current study will be conducted with the aim of evaluating the effect of discharge plan on patients' readiness to discharge after allogeneic stem cells transplantation.

\section{Theoretical framework}

This study will adopt King's theory of goal attainment as a theoretical framework. According to nursing theory, (2016), this nursing theory focuses on dynamic Interaction between two or more persons to meet specific goal in specific time. It consists of three systems which include:

Personal system-the individual

- Interpersonal system -individuals interacting with one another 
- Social system-groups of people in a community or society sharing common goals, interests and values.

The series of actions, reactions and interactions that take place between the nurse and client based on mutual perception and judgment of both are described in (FIGURE 1).

The ultimate result is the shard goal attainment.

King's theory will be applied to meet the goal of providing patients after (AHSCT) with health information needed to become ready to discharge from the hospital (FIGURE 2). It is done through the application of the following concepts postulated by King's theory include growth and development, communication, stress, time, and satisfaction:

\section{Growth and development:}

Assessing the patients' age, gender, their expectation and goals from educational sessions.

\section{- Communication:}

Patient and researcher will communicate to set a mutual goal and collaborate to meet this goal.

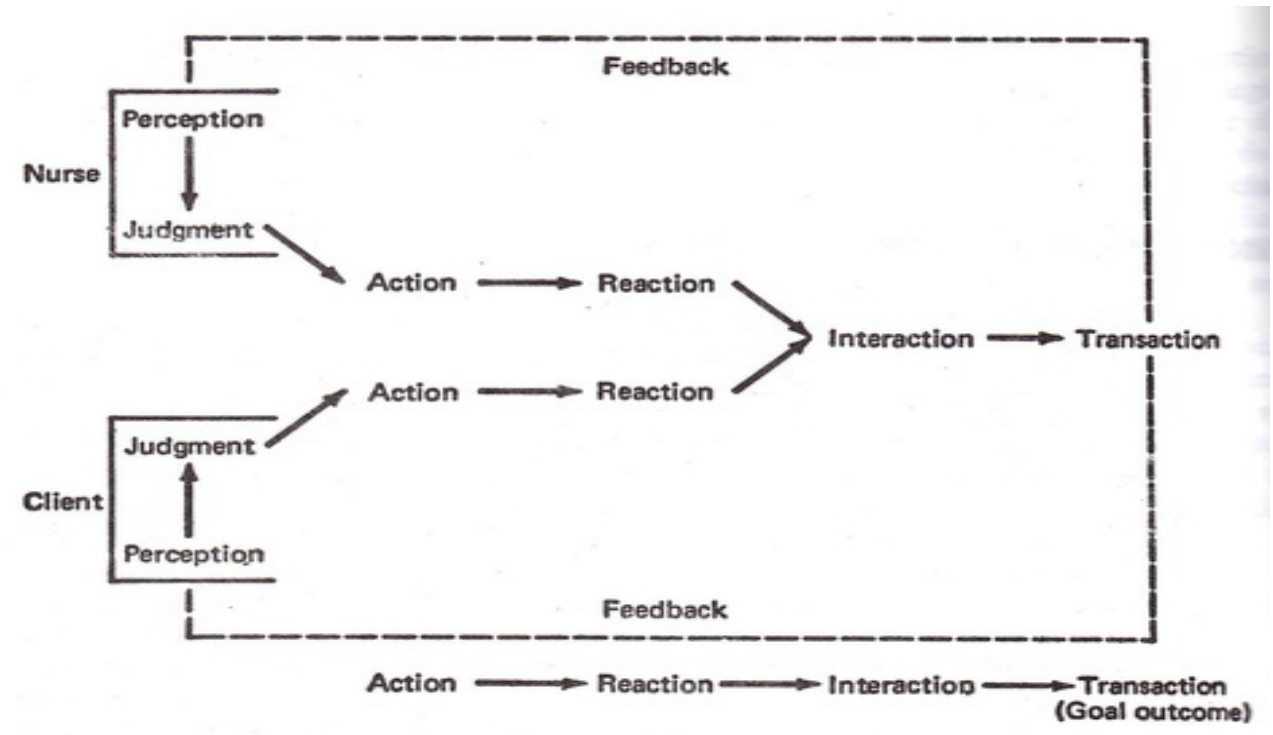

FIGURE 1. King's theory of goal attainment.

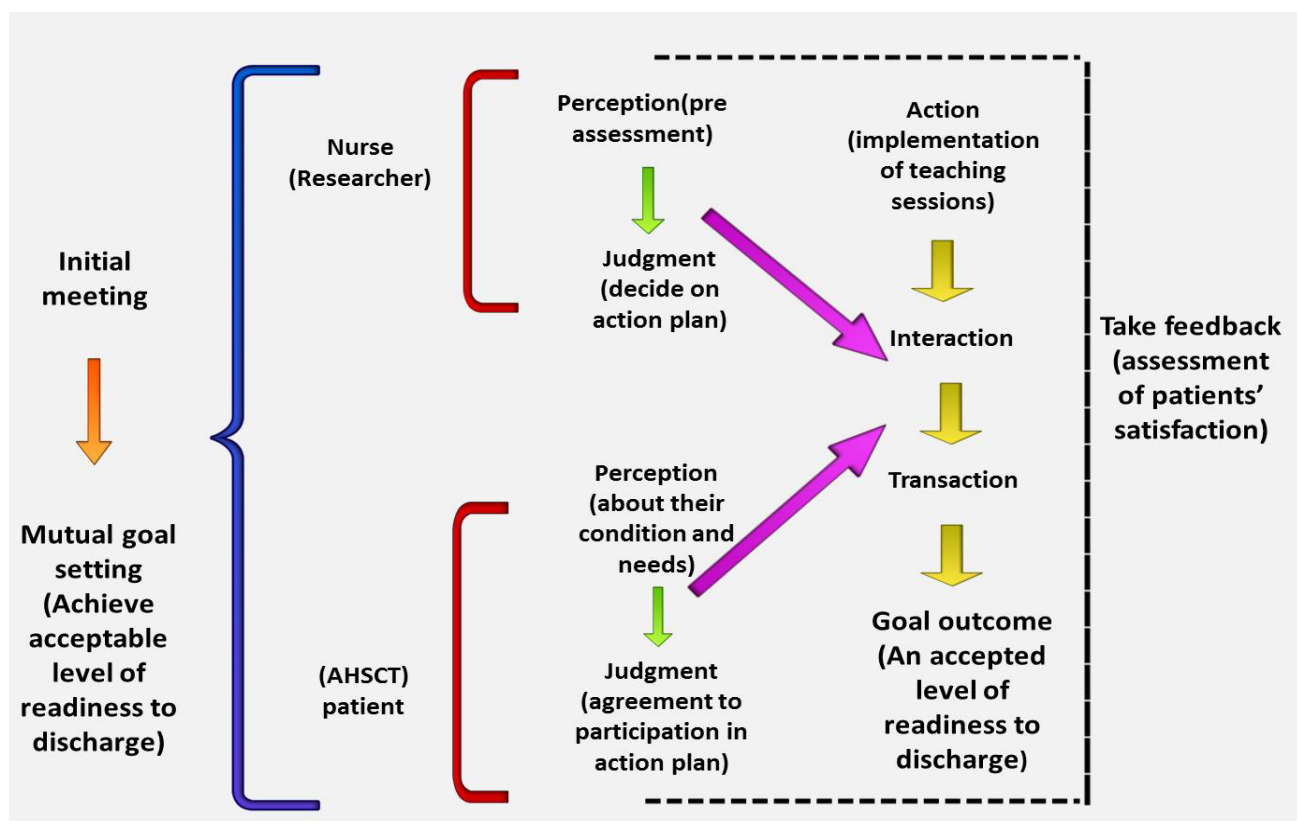

FIGURE 2. Adaptation of King's theory of goal attainment in the current study. 


\section{- Stress:}

Hospital discharge after (AHSCT) can be stressful event for the patients and may cause anxiety and depression for them, so the researcher will assess anxiety level and depression for these patients and provide complete information using proper communication channels to reduce anxiety and depression.

\section{- Time:}

Patients after stem cells transplantation complain from long time of hospital isolation, it can cause psychological upset. So the researcher will fill part of this time by interacting with the patients, providing them with educational sessions, determine time to perform different types of activities intended to be gained to help them deal properly with their own needs after discharge.

\section{Satisfaction:}

Researcher will assess patients' satisfaction by asking them to respond to questions at least two times at the end of sessions, then; modification in the session will be done if needed.

\section{Experimental method}

One group pre-post-test quasi-experimental design was used to achieve the aim of the current study.

\section{Procedure}

An official permission was obtained from the hospital director, and director of stem cells transplantation unit for conducting the study. Measures were taken to protect the patients' ethical rights. Each patient was pre informed and asked to sign a written consent after clarifying the purpose and the nature of the study. The study was conducted on four phases; assessment, planning, implementation, and evaluation phase.

\section{- Assessment or initial phase:}

It involves collecting data through reviewing the literature dating back for at least 5 years using scientific data base. Besides ensuring the accessibility of subjects, the environment as well as facilities needed to perform the proposed study. Also, the researcher was selecting the study design, sample size and the appropriate tools to collect pertinent data of the study.

\section{- Planning phase:}

Based on the outcome of the previous phase, final decision about time, frequency, of patients' educational sessions and its content was taken. Final format of the study tools and the patients discharge guide were developed.

\section{- Implementation phase:}

Firstly, the researcher was communicated with the head nurse of stem cells transplantation unit to identify the newly admitted patients and immediate post-transplant patients, then; the researcher was conduct an initial meeting with each patient individually in his/her room (before or immediate after stem cells transplantation) for 10 minutes, in this first patient contact, the researcher was introduced herself to the patient, explain the nature of the study and take the initial agreement from the patient to participate in the study. Then the patients who were meet the initial inclusion criteria for the study was approached individually for 1 hour by the researcher (after one week from date of transplantation). Pre assessment was done for each patient by using (PFS), (HADS) and pre-post patients' knowledge assessment test to select which patients were included in the study (final inclusion criteria). Pre assessment was field by the researcher because all communication between the researcher and each patient through glass or rubber transparency screen.

In the same session, an individualized interview was conducted with each patient to collect the related personal and medical data; patients were also asked about their expectation and goals regarding their readiness to discharge. Four educational sessions were started from second week after transplantation (two session per week) each session was last from 30 to 45 minutes with the aim of training the patients on how to perform pursued lips breathing exercise and active (ROM) exercise, also, to instruct the patients and their available caregivers about follow-up dietary instructions, medication regimen, precautions about hygienic care, instructions about home environment, follow up of medical care, signs of complications may developed at home and how they deal with them.

During each session, the researcher was give break time according to patients' needs and used teaching (pictures and audio-visual materials) to 
facilitate the information given for the patients. Also, the researcher was taking an immediate feedback from them and assesses patients' satisfaction two times at the end of sessions; no modification in the way of explanation was needed. Each patient was handed in a copy of the instructional guide to assist their understanding of the learned material.

\section{- Evaluation phase:}

After finishing all sessions, one postassessment was carried within one week before patients' hospital discharge by the researcher using the study tools adapted (PFS), adapted (HADS) and pre-post patients' knowledge tool. The collected post-assessment scores were analyzed and compared statistically to evaluate the effect of discharge plan on patients' readiness to discharge after stem cells transplantation.

\section{Results and analysis of data}

Statistical findings of the current study are presented in four main sections as follows:

Section I: Descriptive statistical findings of the studied patients related to personal and medical data.

Section II: Descriptive statistical findings related to fatigue level of the studied patients post (AHSCT) before and after receiving the education relevant to discharge plan.

Section III: Descriptive statistical findings related to hospital anxiety and depression level of the studied patients post (AHSCT) before and after receiving the education relevant to discharge plan.

Section IV: Descriptive statistical findings related to knowledge level among post (AHSCT) patients before and after before and after receiving the education relevant to discharge plan.

\section{- Section (I) part 1: Descriptive statistics findings related to personal characteristics of the patients}

Regarding studied patients' age, (46.7\%) of them are within the age ranged between 18 to less than 28 with a mean of $(29 \pm 7.9)$, and most of them $(66.7 \%)$ were males. About marital status, $(63.3 \%)$ of the studied patients were married. According to educational level (26.7\% and $23.3 \%)$ of studied patients have first university degree and secondary school

\begin{tabular}{|c|c|c|c|}
\hline Item & No. & $\%$ & \pm SD \\
\hline $\begin{array}{l}\text { Age } \\
\qquad \begin{array}{l}18-<28 \text { years } \\
28-<38 \text { years } \\
38-<48 \text { years } \\
48-<58 \text { years }\end{array}\end{array}$ & $\begin{array}{c}14 \\
11 \\
3 \\
2\end{array}$ & $\begin{array}{c}46.7 \\
36.7 \\
10 \\
6.6\end{array}$ & $29 \pm 7.9$ \\
\hline $\begin{array}{l}\text { Sex } \\
\text { Male } \\
\text { Female }\end{array}$ & $\begin{array}{l}20 \\
10\end{array}$ & $\begin{array}{l}66.7 \\
33.3\end{array}$ & \\
\hline $\begin{array}{l}\text { Marital status } \\
\text { Married } \\
\text { Single }\end{array}$ & $\begin{array}{l}19 \\
11\end{array}$ & $\begin{array}{l}63.3 \\
36.7\end{array}$ & \\
\hline $\begin{array}{l}\text { Education } \\
\text { University degree } \\
\text { Technical institute } \\
\text { diploma } \\
\text { Secondary school } \\
\text { diploma } \\
\text { Can read and write } \\
\text { Can't read or write }\end{array}$ & $\begin{array}{l}8 \\
4 \\
7\end{array}$ & $\begin{array}{c}26.7 \\
13.3 \\
\\
23.3 \\
\\
16.7 \\
20\end{array}$ & \\
\hline $\begin{array}{l}\text { Type of work } \\
\text { Office work } \\
\text { Salesman } \\
\text { Unemployed }\end{array}$ & $\begin{array}{c}0 \\
15 \\
15\end{array}$ & $\begin{array}{c}0 \\
50 \\
50\end{array}$ & \\
\hline
\end{tabular}

diploma respectively (TABLE 1). According to type of work half of the studied patients were salesman and another half of them were unemployed. With reference to income, most of studied patients (63.3\%) had enough income. In relation to number of relatives they are living with $(43.3 \%)$ of the studied patients had 1 to 3 relatives sharing their residence. Most of the studied patients (96.7\%) live in flats, $(63.3 \%)$ of them had private room and (93.4\%) of them their place of residents were well ventilated.

Section II: Descriptive statistical findings related to fatigue level among post (AHSCT) patients before and after conducting discharge plan.

In relation to fatigue level before conducting discharge plan, most of the studied patients (86.6\%) had moderate fatigue level while $(13.4 \%)$ of them had extreme fatigue level (FIGURES 3-4). About fatigue level after conducting discharge plan, most of the studied patients $(73.4 \%)$ had moderate level of fatigue and only $(26.6 \%)$ of them had mild level. 
Patients' medical diagnosis

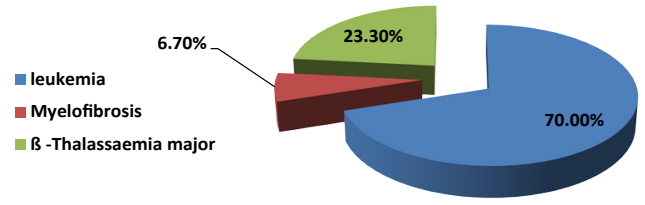

FIGURE 3. Percentage distribution of patients' medical diagnosis $(n=30)$.

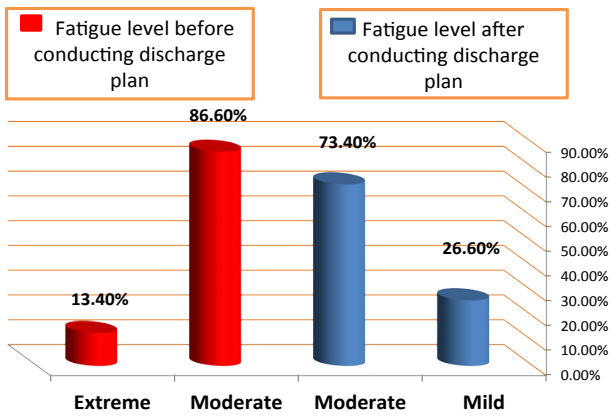

FIGURE 4. Percentage distribution of fatigue level of post (AHSCT) patients before and after conducting discharge plan $(n=30)$.

\section{Section III: Descriptive statistical} findings related to anxiety level and depression among post (AHSCT) patients before and after conducting discharge plan.

With reference to level of hospital anxiety before conducting discharge plan, most of the studied patients $(83.4 \%)$ had anxiety and only (16.4\%) of them borderline before conducting discharge plan, while $(76.6 \%)$ of the studied patients had no anxiety and (23.4\%) of them borderline to have anxiety after conducting discharge plan (FIGURE 5).

In relation to level of hospital depression before conducting discharge plan; most of the studied patients $(66.6 \%)$ have borderline of depression while $(23.4 \%)$ of them had depression and only (10\%) of patients had no depression before conducting discharge plan (FIGURE 6). About level of hospital depression after conducting discharge plan, the majority of the studied patients $(60 \%)$ had no depression while $(33.4 \%)$ of them showed borderline level of depression and $(6.6 \%)$ of the studied patients had depression.

Section IV: Results to answer research hypothesis (III)
Descriptive statistical findings related to knowledge level among post (AHSCT) patients before and after conducting discharge plan.

In relation to questions related to infection

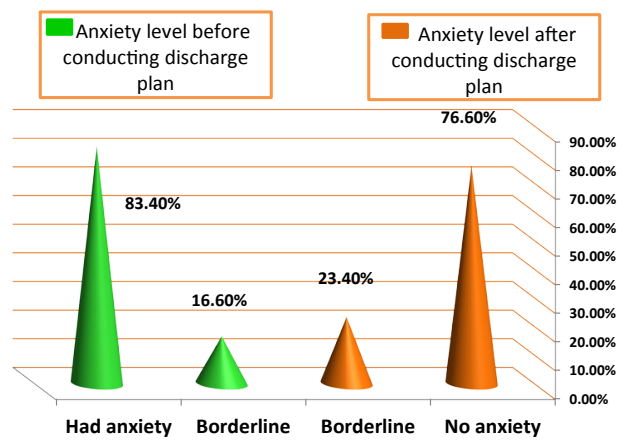

FIGURE 5. Percentage distribution of level of hospital anxiety of patients post (AHSCT) before and after conducting discharge plan $(n=30)$.

Level of patients' depression before conducting discharge plan

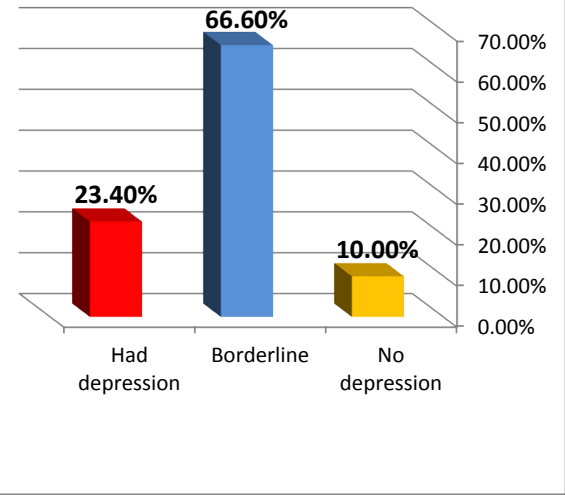

Level of patients' depression after conducting discharge plan

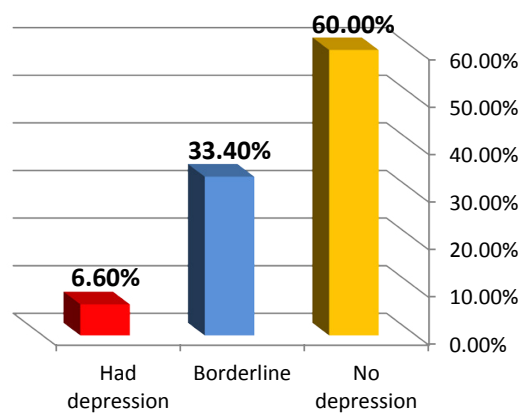

FIGURE 6. Percentage distribution of level of hospital depression of patients post (AHSCT) before and after conducting discharge plan $(n=30)$. 
control; more than $(90 \%)$ of the studied patients had incorrect answer before conducting discharge plan about questions related to (sun exposure, not to sit in a room with walls panted with oil or plastic paints, signs of infection, using of face mask when going outside home, and teeth cleaning) followed by questions related to (living with children, using of hydrogen peroxide for mouth cleaning, wearing new clothes after washing them, and wearing

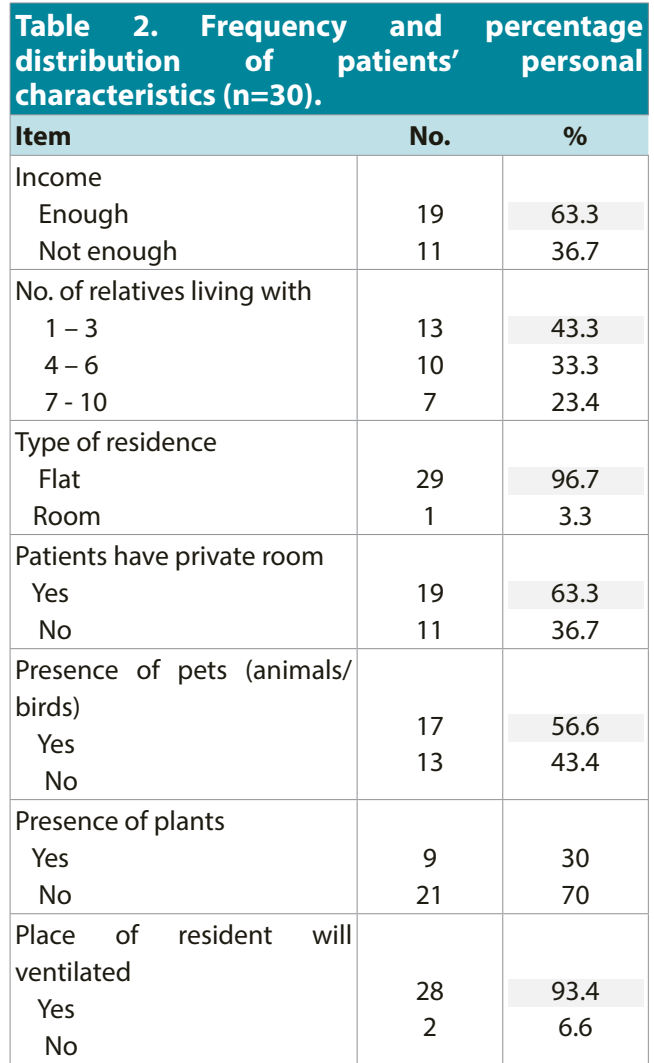

eye lenses when needed) (TABLES 2-6) and more than $(70 \%)$ of these patients had incorrect answer about questions related to (using of insecticides, presence of room carpets, home cleaning, presence of pets at home, and children visits elimination) followed by questions related to (presence of plants at home, closing room windows, presence of animals at home, using the mosquito repellent tables in the living room, toilet cleaning, and alcohol using for different body parts).

While more than $(90 \%)$ of these patients had correct answer about the same questions after conducting discharge plan. Total mean scores of incorrect answers of patients about questions related to infection control before conducting discharge plan was $(65.4 \%)$ while total mean scores of correct answer of them about the same questions was (98.3\%) after conducting discharge plan (FIGURES 5-10).

In relation to questions related to nutrition more than $(90 \%)$ of the studied patients had incorrect answers before conducting discharge plan about questions related to (eating raw vegetables, not to eat protein reach food, drink $500 \mathrm{cc}$ of water, eating light food such as grilled fish, eat reheated food, eating cheese and sweet foods, and not to eat mayonnaise, cream, nuts and ice cream) followed by questions related to (eat sterile food, and eat plenty of saved food) and more than $(50 \%)$ of them had incorrect answers about questions related to (washing vegetables with water and vinegar before cooking, and avoid hot and sweet food) (TABLE 3 and 7).

Table 3. Frequency and percentage distribution of knowledge level about infection control of post (AHSCT) patients before and after conducting discharge plan ( $n=30)$.

\begin{tabular}{|c|c|c|c|c|c|c|c|c|}
\hline \multirow{3}{*}{ Question no. } & \multicolumn{4}{|c|}{ Before conducting discharge plan } & \multicolumn{4}{|c|}{ After conducting discharge plan } \\
\hline & \multicolumn{2}{|c|}{ Correct } & \multicolumn{2}{|c|}{ Incorrect } & \multicolumn{2}{|c|}{ Correct } & \multicolumn{2}{|c|}{ Incorrect } \\
\hline & No. & $\%$ & No. & $\%$ & No. & $\%$ & No. & $\%$ \\
\hline Sun exposure & 1 & 3.3 & 29 & 96.7 & 28 & 93.3 & 2 & 6.7 \\
\hline Using of insecticides & 7 & 23.3 & 23 & 76.7 & 30 & 100 & 0 & 0 \\
\hline Presence of plants at home & 11 & 36.7 & 19 & 63.3 & 30 & 100 & 0 & 0 \\
\hline Closing room windows & 11 & 36.7 & 19 & 63.3 & 28 & 93.3 & 2 & 6.7 \\
\hline Presence of animals at home & 9 & 30 & 21 & 70 & 30 & 100 & 0 & 0 \\
\hline Living with children & 5 & 16.3 & 25 & 83.7 & 30 & 100 & 0 & 0 \\
\hline $\begin{array}{l}\text { Not to sit in a room with walls } \\
\text { painted with oil or plastic paint }\end{array}$ & 2 & 6.7 & 28 & 93.3 & 29 & 96.7 & 1 & 3.3 \\
\hline Presence of room carpets & 7 & 23.3 & 23 & 76.7 & 27 & 90 & 3 & 10 \\
\hline Home cleaning & 7 & 23.3 & 23 & 76.7 & 30 & 100 & 0 & 0 \\
\hline $\begin{array}{l}\text { Using the mosquito repellent } \\
\text { tablets in the living room. }\end{array}$ & 10 & 33.3 & 20 & 66.7 & 28 & 93.3 & 2 & 6.7 \\
\hline Toilet cleaning & 10 & 33.3 & 20 & 66.7 & 30 & 100 & 0 & 0 \\
\hline Presence of birds at home & 6 & 20 & 24 & 80 & 30 & 100 & 0 & 0 \\
\hline
\end{tabular}




\begin{tabular}{|c|c|c|c|c|c|c|c|c|}
\hline \multirow{3}{*}{ Question no. } & \multicolumn{8}{|c|}{ Before conducting discharge plan After conducting discharge plan } \\
\hline & \multicolumn{2}{|c|}{ Correct } & \multicolumn{2}{|c|}{ Incorrect } & \multicolumn{2}{|c|}{ Correct } & \multicolumn{2}{|c|}{ Incorrect } \\
\hline & No. & $\%$ & No. & $\%$ & No. & $\%$ & No. & $\%$ \\
\hline Check body temperature & 3 & 10 & 27 & 90 & 30 & 100 & 0 & 0 \\
\hline Signs of infection & 0 & 0 & 30 & 100 & 30 & 100 & 0 & 0 \\
\hline Alcohol using for different body parts & 12 & 40 & 18 & 60 & 30 & 100 & 0 & 0 \\
\hline $\begin{array}{l}\text { Using of face mask when going outside } \\
\text { home }\end{array}$ & 0 & 0 & 30 & 100 & 30 & 100 & 0 & 0 \\
\hline Teeth cleaning & 1 & 3.3 & 29 & 96.7 & 30 & 100 & 0 & 0 \\
\hline $\begin{array}{l}\text { Using of hydrogen peroxide for mouth } \\
\text { cleaning }\end{array}$ & 4 & 13.3 & 26 & 86.7 & 30 & 100 & 0 & 0 \\
\hline Wearing new closes after washing them & 3 & 10 & 27 & 90 & 30 & 100 & 0 & 0 \\
\hline Children visits elimination & 7 & 23.3 & 23 & 76.7 & 30 & 100 & 0 & 0 \\
\hline Wearing eye lenses when needed & 4 & 13.3 & 26 & 86.7 & 30 & 100 & 0 & 0 \\
\hline $\begin{array}{l}- \\
x\end{array}$ & 7.28 & 34.6 & 13.72 & 65.4 & 29.5 & 98.3 & 0.5 & 1.7 \\
\hline
\end{tabular}

Table 5. Frequency and percentage distribution of knowledge level about nutrition of post (AHSCT) patients before and after conducting discharge plan $(n=30)$.

\begin{tabular}{|c|c|c|c|c|c|c|c|c|}
\hline \multirow{3}{*}{ Question no. } & \multicolumn{4}{|c|}{ Before conducting discharge plan } & \multicolumn{4}{|c|}{ After conducting discharge plan } \\
\hline & \multicolumn{2}{|c|}{ Correct } & \multicolumn{2}{|c|}{ Incorrect } & \multicolumn{2}{|c|}{ Correct } & \multicolumn{2}{|c|}{ Incorrect } \\
\hline & No. & $\%$ & No. & $\%$ & No. & $\%$ & No. & $\%$ \\
\hline Eating raw vegetables & 0 & 0 & 30 & 100 & 28 & 93.3 & 2 & 6.7 \\
\hline Eating sterile food & 9 & 30 & 21 & 70 & 30 & 100 & 0 & 0 \\
\hline Not to eat protein reach food & 1 & 3.3 & 29 & 96.7 & 30 & 100 & 0 & 0 \\
\hline Drinking $500 \mathrm{cc}$ of water & 0 & 0 & 30 & 100 & 30 & 100 & 0 & 0 \\
\hline Eating light foods such as grilled fish & 0 & 0 & 30 & 100 & 30 & 100 & 0 & 0 \\
\hline Eating reheated food & 2 & 6.7 & 28 & 93.3 & 30 & 100 & 0 & 0 \\
\hline Eating plenty of saved food & 5 & 16.7 & 25 & 83.3 & 29 & 96.7 & 1 & 3.3 \\
\hline $\begin{array}{l}\text { Washing vegetables with water and } \\
\text { vinegar before cooking }\end{array}$ & 12 & 40 & 18 & 60 & 28 & 93.3 & 2 & 6.7 \\
\hline Avoiding hot and sweaty foods & 13 & 43.3 & 17 & 56.7 & 30 & 100 & 0 & 0 \\
\hline Eating cheese and fresh fruit & 0 & 0 & 30 & 100 & 30 & 100 & 0 & 0 \\
\hline $\begin{array}{l}\text { Not to eat mayonnaise, cream, nuts } \\
\text { and ice cream }\end{array}$ & 0 & 0 & 30 & 100 & 28 & 93.3 & 2 & 6.7 \\
\hline $\bar{x}$ & 3.8 & 34.5 & 26.2 & 65.5 & 29.3 & 97.6 & 0.7 & 2.4 \\
\hline
\end{tabular}

Table 6. Frequency and percentage distribution of knowledge level about medication regimin, exercise and care of venous access (Hickman) of post (AHSCT) patients before and after conducting discharge plan $(n=30)$.

\begin{tabular}{|c|c|c|c|c|c|c|c|c|}
\hline \multirow{3}{*}{ Question no. } & \multicolumn{4}{|c|}{ Before conducting discharge plan } & \multicolumn{4}{|c|}{ After conducting discharge plan } \\
\hline & \multicolumn{2}{|c|}{ Correct } & \multicolumn{2}{|c|}{ Incorrect } & \multicolumn{2}{|c|}{ Correct } & \multicolumn{2}{|c|}{ Incorrect } \\
\hline & No. & $\%$ & No. & $\%$ & No. & $\%$ & No. & $\%$ \\
\hline Missing dose of medication & 1 & 3.3 & 29 & 96.7 & 30 & 100 & 0 & 0 \\
\hline $\begin{array}{l}\text { Medication dose when side effects } \\
\text { occur }\end{array}$ & 1 & 3.3 & 29 & 96.7 & 30 & 100 & 0 & 0 \\
\hline $\begin{array}{l}\text { Performing long-distance exercise } \\
\text { regularly }\end{array}$ & 6 & 20 & 24 & 80 & 30 & 100 & 0 & 0 \\
\hline Breathing exercises & 9 & 30 & 21 & 70 & 30 & 100 & 0 & 0 \\
\hline $\begin{array}{l}\text { Avoiding bathing to keep venous } \\
\text { access }\end{array}$ & 0 & 0 & 30 & 100 & 30 & 100 & 0 & 0 \\
\hline Injecting venous access with heparin & 3 & 10 & 27 & 90 & 30 & 100 & 0 & 0 \\
\hline Disinfecting the insertion site & 4 & 13.3 & 26 & 86.7 & 30 & 100 & 0 & 0 \\
\hline $\bar{x}$ & 3.4 & 11.4 & 26.6 & 88.6 & 30 & 100 & 0 & 0 \\
\hline
\end{tabular}


Level of total patients' knowledge about infection control

- Satisfactory level Unsatisfactory level

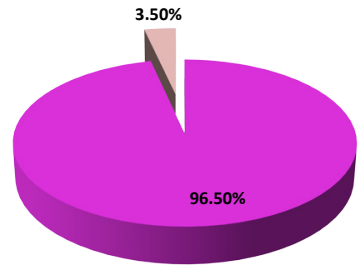

FIGURE 7. Percentage distribution of level of hospital anxiety of patients post (AHSCT) before and after conducting discharge plan $(n=30)$.

Level of patients' total knowledge about nutrition

- Satisfactory level - Unsatisfactory level

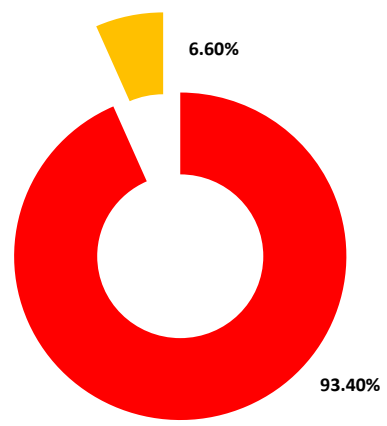

FIGURE 8. Total level of total knowledge about nutrition among post (AHSCT) patients after conducting discharge plan $(n=30)$.

Level of total patients' knowledge about medication, exercise and care of (Hickman)

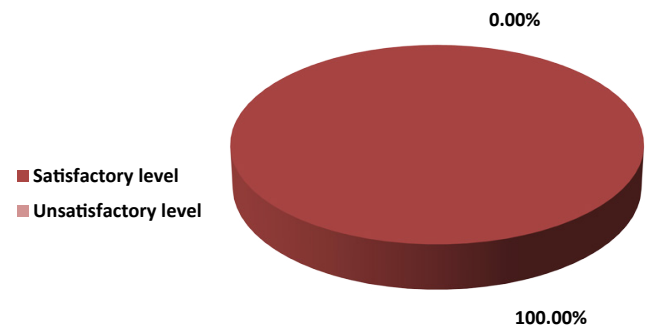

FIGURE 9. Level of total knowledge about medication, exercise and care of venous access (Hickman) control among post (AHSCT) patients after conducting discharge plan $(n=30)$.

While more than $(90 \%)$ of these patients had correct answers about the same questions. Total mean scores of incorrect answers of patients about questions related to nutrition was (65.5\%) before conducting discharge plan while total mean scores of correct answers of patients about the same questions was (97.6\%) after conducting discharge plan.

With reference to questions about medication regimen, most of the studied patients than $(96.7 \%)$ had incorrect answers before conducting discharge plan about questions related to (missing dose of medication, medication dose when side effects occur, before conducting discharge plan and (100\%) of them had correct answers about the same question after conducting discharge plan. In relation to questions related to exercises, more than $(70 \%)$ of patients had incorrect answers about questions related to (performing long-distance exercise regularly, and breathing exercises while $(100 \%)$ of them had correct answers of the same questions after conducting discharge plan (TABLE 4).

About questions related to care of venous access (Hickman), more than (80\%) of the studied patients had incorrect answers about questions related to (avoiding bathing to keep venous access, injecting venous access with heparin, and disinfect site of insertion) before conducting discharge plan, and total number of them their answers were correct about the same questions after conducting discharge plan. Total mean scores of incorrect answers of questions of patients about medication regimen, exercises, and care of venous access before conducting discharge plan was $(88.6 \%)$ while total mean scores of correct answers about the same questions of patients after conducting discharge plan were (100\%) (FIGURES 11,12).

In relation to questions related to sexual relation, more than $(50 \%)$ of the studied patients had incorrect answers about questions related to (sexual relation immediate after discharge, and sexual relation can affected by transplantation) before conducting discharge plan and (100\%) of these patients had correct answers about the same questions after conducting discharge

\footnotetext{
Level of patients' knowledge about sexual relation, follow-up and returne to work or school
}

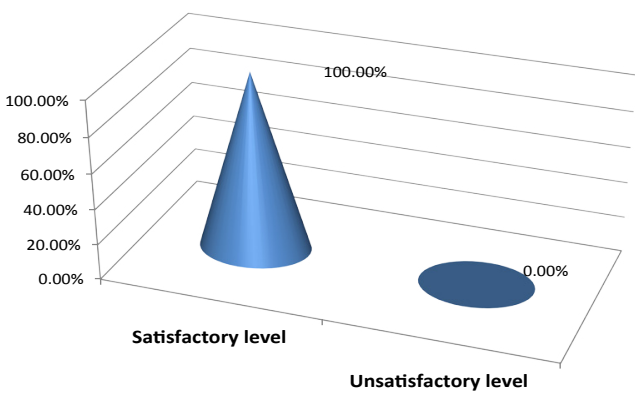

FIGURE 10. Level of total knowledge about medication, exercise and care of venous access (Hickman) control among post (AHSCT) patients after conducting discharge plan $(n=30)$. 
Table 7. Frequency and percentage distribution of knowledge level about sexual relation, follow-up and return to work or school of post (AHSCT) patients before and after conducting discharge plan $(n=30)$.

\begin{tabular}{|c|c|c|c|c|c|c|c|c|}
\hline \multirow{3}{*}{ Question no. } & \multicolumn{4}{|c|}{ Before conducting discharge plan } & \multicolumn{4}{|c|}{ After conducting discharge plan } \\
\hline & \multicolumn{2}{|c|}{ Correct } & \multicolumn{2}{|c|}{ Incorrect } & \multicolumn{2}{|c|}{ Correct } & \multicolumn{2}{|c|}{ Incorrect } \\
\hline & No. & $\%$ & No. & $\%$ & No. & $\%$ & No. & $\%$ \\
\hline $\begin{array}{l}\text { Sexual relation immediate after } \\
\text { discharge }\end{array}$ & 14 & 46.7 & 16 & 53.3 & 30 & 100 & 0 & 0 \\
\hline $\begin{array}{l}\text { Sexual relation can affected by } \\
\text { transplantation }\end{array}$ & 15 & 50 & 15 & 50 & 30 & 100 & 0 & 0 \\
\hline Follow-up for one month & 0 & 0 & 30 & 100 & 30 & 100 & 0 & 0 \\
\hline Patients re-immunization & 0 & 0 & 30 & 100 & 30 & 100 & 0 & 0 \\
\hline Direct blood transfusion & 0 & 0 & 30 & 100 & 30 & 100 & 0 & 0 \\
\hline Paying blood or blood components & 1 & 3.3 & 29 & 96.7 & 30 & 100 & 0 & 0 \\
\hline $\begin{array}{l}\text { Return to work or school direct after } \\
\text { discharge }\end{array}$ & 11 & 36.7 & 19 & 63.3 & 30 & 100 & 0 & 0 \\
\hline Driving a care by the patient & 10 & 33.3 & 20 & 66.7 & 30 & 100 & 0 & 0 \\
\hline $\bar{x}$ & 6.3 & 21 & 23.7 & 79 & 30 & 100 & 0 & 0 \\
\hline
\end{tabular}

Level of total patients knowledge about complications after conducting discharge plan

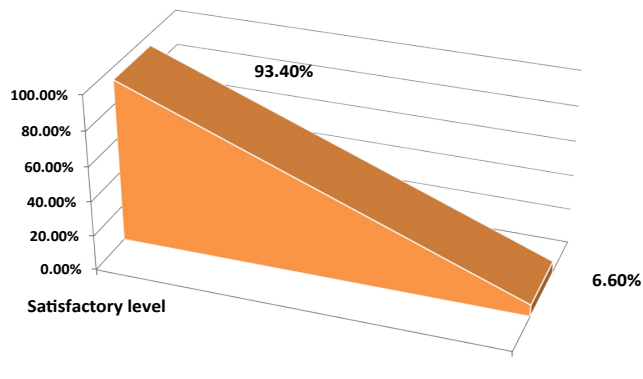

Unsatisfactory level

FIGURE 11. Level of total knowledge about complications among post (AHSCT) patients after conducting discharge plan $(n=30)$.

Total level of patients' knowledge before conducting discharge plan

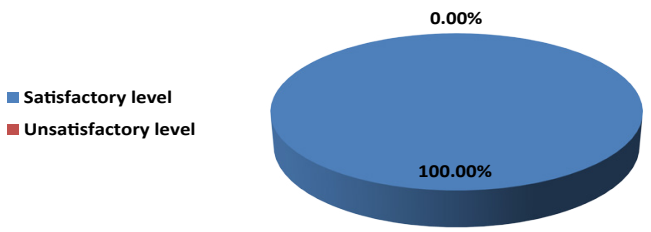

FIGURE 12. Level of total patients' knowledge post (AHSCT) before conducting discharge plan $(n=30)$.

plan (TABLE 5). About questions related to follow-up, more than (95\%) of the studied patients had incorrect answer about questions related to (follow-up for one month, patients re-immunization, direct blood transfusion, and paying blood or blood components before conducting discharge plan, while total number of them had correct answer about the same questions after conducting discharge plan.
According to questions related to return to work or school, more than $(60 \%)$ of the studied patients had incorrect answers about questions related to (return to work or school direct after discharge, and driving a care by the patient) before conducting discharge plan but total number had correct answers about the same questions after conducting discharge plan. Total mean scores of incorrect answers of questions of patients about sexual relation, follow-up, and return to work or school before conducting discharge plan was (79\%) while total mean scores of correct answers about the same questions of patients after conducting discharge plan were (100\%).

According to questions related to complications may occurs after (AHSCT), $(90 \%)$ of the studied patients had incorrect answers before conducting discharge plan about questions related to (eating high fibers' food, and minimize legumes such as beans and lentils) followed by questions related to (drink small amount of fluids during nausea, and sleep directly after eating) and more than (70\%) of them had incorrect answers about questions related to (eating large amount of food, and using a few spices such as mint, basil and curry) and only $(46.7 \%)$ of these patients ad incorrect answers about question related to (drink coffee) (TABLE 8).

While total numbers of the same patients had correct answers after conducting discharge plan about the same questions. Total mean scores of incorrect answers of questions of patients about 
Table 8. Frequency and percentage distribution of knowledge level about complications of post (AHSCT) patients before and after conducting discharge plan $(n=30)$.

\begin{tabular}{|c|c|c|c|c|c|c|c|c|}
\hline \multirow{3}{*}{ Question no. } & \multicolumn{4}{|c|}{ Before conducting discharge plan } & \multicolumn{4}{|c|}{ After conducting discharge plan } \\
\hline & \multicolumn{2}{|c|}{ Correct } & \multicolumn{2}{|c|}{ Incorrect } & \multicolumn{2}{|c|}{ Correct } & \multicolumn{2}{|c|}{ Incorrect } \\
\hline & No. & $\%$ & No. & $\%$ & No. & $\%$ & No. & $\%$ \\
\hline Eating large amount of foods & 7 & 23.3 & 23 & 76.7 & 30 & 100 & 0 & 0 \\
\hline $\begin{array}{l}\text { Using a few spices such as mint, basil } \\
\text { and curry }\end{array}$ & 8 & 26.7 & 22 & 73.3 & 30 & 100 & 0 & 0 \\
\hline Drinking coffee & 16 & 53.3 & 14 & 46.7 & 30 & 100 & 0 & 0 \\
\hline $\begin{array}{l}\text { Drinking small amount of fluid during } \\
\text { nausea }\end{array}$ & 6 & 20 & 24 & 80 & 30 & 100 & 0 & 0 \\
\hline Sleeping directly after eating & 3 & 10 & 27 & 90 & 30 & 100 & 0 & 0 \\
\hline Eating high fibers foods & 2 & 6.7 & 28 & 93.3 & 30 & 100 & 0 & 0 \\
\hline $\begin{array}{l}\text { Minimizing legumes such as beans and } \\
\text { lentils }\end{array}$ & 2 & 6.7 & 28 & 93.3 & 30 & 100 & 0 & 0 \\
\hline $\bar{x}$ & 6.28 & 20.9 & 23.72 & 79.1 & 30 & 100 & 0 & 0 \\
\hline
\end{tabular}

complications before conducting discharge plan was $(79.1 \%)$ while total mean scores of correct answers about the same questions of patients after conducting discharge plan were (100\%).

\section{Conclusion}

In light of the current study findings it could be concluded that; combination of informational structures with different types of exercises as (ROM \& pursed lips breathing exercises) may be of great value in enhancing patients' knowledge and reducing their psychological status (decrease level of anxiety and depression) and raise awareness about selfcare at home after hospital discharge for patients prior to post (AHSCT). Performing of (ROM \&pursed lips breathing) exercises for short time cannot improve fatigue level for these patients.

\section{Acknowledgments}

My sincere gratitude should be submitted first of all to ALLAH for helping me to manage the hard time I faced in the completion of this work and who always cares for me.

No words could express my feeling of gratitude and respect to Prof. Kairia Abo Bakr Elsawy, professor of Medical Surgical Nursing, Faculty of Nursing, Cairo University for her endless guidance, support, patience throughout the work. I felt greatly honored to work under her supervision.

I would like to express my deepest gratitude and appreciation to Professor Hanaa Yossry Hassim professor of Medical Surgical Nursing, Faculty of Nursing, Cairo University who always gave me much of her time, effort, guidance, suggestion sincere advice, continuous encouragement and tolerance throughout the progress of this work.

I want to express my deepest thanks and gratitude to Dr. Gamal Eldin Mohamed Fathy, Consultant of Hematological Diseases and Bone Marrow Transplantation Nasser Institute for Research and Treatment for his valuable guidance and constant encouragement.

I am deeply grateful to all patients who accepted to participate in this study; I would like to thank the administrators of hemodialysis units Cairo University Hospitals for allowing me the opportunity to collect data.

Special thanks and gratitude are devoted to head of nurse and all nurses at stem cells transplantation unit at Nasser Institute for Research and Treatment for their helping and facilitation of work.

In addition, I would like to thank all faculty members and my colleagues at Faculty of Nursing, Cairo University for their guidance.

I acknowledge my friends for the continued encouragement.

Last but not least thanks for everyone who helped me to accomplish this work. 


\section{REFERENCES}

Eder S, Beohou E, Labopin M, et al. Thiotepa-based conditioning for allogeneic stem cell transplantation in acute lymphoblastic leukemia-a survey from the acute leukemia working party of the European society for blood and marrow transplantation. Am. J. Hematol. 92(1), 18-22 (2017).

Dahabreh IJ, Adam GP, Halladay CW, et al. Diagnosis of right lower quadrant pain and suspected acute appendicitis. Report No.: 15(16)-EHC025-EF Agency for Healthcare Research and Quality (US) (2015).
William BM, Allen MS, Loberiza FR Jr, et al. Phase I/II study of bortezomibBEAM and autologous hematopoietic stem cell transplantation for relapsed indolent non-Hodgkin lymphoma, transformed, or mantle cell lymphoma. Biol. Blood Marrow Transplant. 20(4), 536-542 (2014).

El-Jawahri A, Traeger L, Greer JA, et al. Effect of inpatient palliative care during hematopoietic stem-cell transplant on psychological distress 6 months after transplant: results of a randomized clinical trial. J. Clin. Oncol. 35(32), 3714-3721 (2017).

Laine J, D’Souza A, Siddiqui S, et al.
Rehabilitation referrals and outcomes in the early period after hematopoietic cell transplantation. Bone Marrow Transplant 50(10), 1352-1357 (2015).

Lishuang M, Yandong W, Shuli L, et al. A comparison of clinical outcomes between endoscopic and open surgery to repair neonatal diaphragmatic hernia. J. Minim. Access Surg. 13(3), 182-187 (2017).

An D. Cochrane Review Brief: Discharge Planning from Hospital to Home. Online J. Issues Nurs. 20(2), 13 (2015). 